DOI https://doi.org/10.32837/app.v0i64.188

УДК 323.2:342.92

Мішин C. I. * $($ HУ «OЮA»)

ORCID ID: https://orcid.org/0000-0003-1439-3303

\title{
ТЕОРЕТИЧНО-МЕТОДОЛОГІЧНІ ЗАСАДИ \\ РЕФОРМУВАННЯ СИСТЕМИ МІСЦЕВОГО \\ САМОВРЯДУВАННЯ
}

\section{THEORETICAL-METHODOLOGICAL FOUNDATIONS OF LOCAL SELF-GOVERNMENT REFORMING}

*Serhii Mishyn - PhD Student at the Political Theories Department, National University "Odesa Law Academy" (23, Fontanska Doroha St., Odesa, Ukraine).

\section{Abstract}

Local self-government is considered in the article as a complex branch of Ukrainian law, which is a set of legal norms that fix and regulate public relations that arise in the process of organizing local self-government and resolving territorial community directly through local self-government bodies, and in the process of implementation certain state powers that local governments may have.

It is established that the institutional reform of local authorities is a prerequisite for the dynamic development of Ukraine. This will overcome their duplication of functions and lack of transparency and will also bring them into line with market conditions. Particular attention should be paid, both in theory and in practical terms, to the study of the impact of the post-totalitarian heritage on the development of power institutions, the mechanisms for achieving a balance between legalization and legitimation of power by effective resolution of existing contradictions.

This process is manifested in two interrelated forms, namely: constitutionalization - the incorporation of the basic principles of the status of political parties into the constitution, and legislative institutionalization as a result of which the legal status of parties receives further regulation in law.

In the scientific-theoretical aspect, local self-government is characterized as a special institution, which at its core does not have a state or state power, based 60 
on a material basis of state property, but a public community, a community whose material basis is an entirely different form of ownership - municipal.

The role of local self-government for the processes of spatial organization of public power is explained by the fact that the power of territorial communities, being an independent kind of public power, by its subject-object composition, nature, essence and the range of performed functions is the most socially oriented form the exercise of public authority and is a powerful catalyst for the formation of civil society since the conscious participation of residents in the process of creating decent living conditions in a certain territory promotes responsibility for solving local problems and thus increases their overall social and civic activity.

Keywords: local self-government, territorial community, united territorial community, perspective plan, decentralization, reform of local self-government.

Місцеве самоврядування сьогодні виступає важливим фактором демократизації суспільного життя, децентралізації управління та необхідною передумовою становлення громадянського суспільства, наближення влади до іiі джерела - народу. Це комплексна галузь українського права, що є сукупністю правових норм, які закріплюють і регулюють суспільні відносини, що виникають у процесі організації місцевого самоврядування і вирішення територіальною громадою безпосередньо через органи місцевого самоврядування питань місцевого значення, а також у процесі реалізації окремих державних повноважень, якими можуть наділятися органи місцевого самоврядування.

Настав час напрактиці змінювати владні інституції, зробити їх реально ефективними і справді прозорими, відновити конструктивний діалог між владою і суспільством, повернути довіру громадян до Президента, Верховної Ради, Кабінету Міністрів, до пересічного українського посадовця.

Мета статтіполягає в узагальненні теоретичних підходів щодо сутності та змісту стратегії розвитку об'єднаної територіальної громади, обгрунтувати теоретико-методологічні та науково-прикладні засади та проблеми організації місцевого самоврядування в умовах децентралізації влади в України.

Аналіз останніх досліджень і публікацій свідчить про те, що феномен інституалізації влади в Україні був об'єктом науковотеоретичного аналізу таких вчених, як: В. Андрущенко, О. Бабкіна, А. Гальчинський, Л. Губерський, Л. Кормич, В. Кремень, І. Курас, Ю. Левенець, С. Наумкіна, Ф. Рудич, Ю. Шемшученко та ін. 
Велике значення мають дослідження, присвячені аналізу окремих аспектів життєдіяльності владних інститутів, а саме роботи В. Баркова, Е. Гансової, А. Єрмоленка, Г. Зеленько, А. Карася, С. Кириченка, I. Кресіної, А. Кудряченка, В. Ребкала, Т. Розової, А. Сіленко, М. Степика та ін.

Значний внесок у розвиток дослідження процесу інституалізації влади зробили такі зарубіжні вчені, як П. Бурдьє, Ю. Габермас, Р. Даль, Р. Дарендорф, Т. Парсонс, Дж. Бінгем, Дж. Сарторі, О. Тофлер, М. Фуко та Ф. Фукуяма.

Необхідною умовою динамічного розвитку України є інституційне реформування органів влади на місцях. Це дозволить подолати їхнє дублювання функцій і нестаток прозорості, а також призведе їх у відповідність до ринкових умов. Термін інституалізація не новий і вже досить тривалий час широко використовується у таких науках, як історія, політологія, соціологія, психологія тощо. Загалом під інституалізацією (лат. Institutum - встановлення, створення) слід розуміти організацію будь-яких нових громадських інститутів, їхнє правове та організаційне закріплення, або унормування інших суспільних відносин.

Політична наука говорить, що інституалізація - це перетворення будь-якого політичного руху чи явища на організовану установу, його формалізація, певне впорядкування процесу. Інституалізація політичних партій - це процес перетворення політичних партій із звичайних асоціацій громадян на повноцінний конституційноправовий інститут.

Такий процес має прояв у двох взаємопов'язаних формах, а саме: конституціоналізації - включенні до конституції основни принципів статусу політичних партій, а також законодавчій інституціоналізації - внаслідок якої правове становище партій отримує подальше регулювання в законі (Политическая наука: словарь-справочник, 2010, с. 26).

Крім того, у психологічній науці розглядається феномен інституалізація конфлікту - що полягає у встановленні чітких норм і правил конфліктної взаємодії, визначенні робочих груп та комісій з управління конфліктом (Кравченко, 2001, с. 246).

У науці “Державне управління” термін інституалізація місцевого самоврядування пропонується розглядати як:

- певну організацію місцевого самоврядування як владного інституту на місцях, що має визначений правовий та організаційний статус; 
- встановлення й розвиток норм і правил життєдіяльності місцевих громад як організованих інституцій, певним чином формалізовані та впорядковані на визначеній території;

- процес перетворення (модернізації) місцевого самоврядування у часовому просторі, набуття ним нових якісних ознак.

Відповідно до усталеної традиції, громада - це адміністративнотериторіальна одиниця, до якої входять одне або кілька поселень і яка є територіальною основою діяльності органів місцевого самоврядування 3 надання населенню основних соціальних послуг.

Демократизація державного управління, яка включає в себе реорганізацію системи територіальної організації органів публічної влади, безпосередньо пов'язана $з$ процесом посилення ролі органів місцевого самоврядування. Проведення адміністративно-територіальної реформи не може і не повинно розглядатись відокремлено від процесів реформування системи місцевого самоврядування.

У науково-теоретичному аспекті місцеве самоврядування характеризується як особливий інститут, який у своїй основі має не державу чи державну владу, які засновані на матеріальній базідержавної власності, а громадську спільноту, общину, матеріальною базою якої є зовсім інша форма власності - муніципальна (Копєйчиков, 1995).

Місцеве самоврядування на практиці втілює інтереси територіальних громад (Коваленко, 1997, с. 73). При цьому роль місцевого самоврядування для процесів просторової організації публічної влади пояснюється тим, що влада територіальних громад, будучи самостійним видом публічної влади, за своїм суб'єктно-об'єктним складом, своєю природою та сутністю, діапазоном здійснюваних нею функцій є найбільш соціально орієнтованою формою здійснення публічної влади, а також виступає потужним каталізатором формування громадянського суспільства, оскільки свідома участь жителів у процесі утворення гідних умов життя на певній території сприяє формуванню у них відповідальності за вирішення місцевих проблем і тим самим підвищує їх загальну соціальну та громадянську активність (Батанов, 2006).

Відповідно до Закону України “Про місцеве самоврядування в Україні" місцеве самоврядування являє собою гарантоване державою право та реальну здатність територіальної громади - жителів села чи добровільного об'єднання у сільську громаду жителів кількох сіл, селища, міста - самостійно або під відповідальність органів та посадових осіб місцевого самоврядування вирішувати питання 
місцевого значення в межах Конституції і законів України. При цьому згідно із вказаним законом органи місцевого само врядування $є$ юридичними особами і наділяються власними повноваженнями, в межах яких діють самостійно і несуть відповідальність за свою діяльність відповідно до закону (Про місцеве самоврядування в Україні: Закон України, 1997).

Конкретні заходи з інституціонального вдосконалення системимісцевого управління повинні грунтуватися на вироблених світовою практикою принципових засадах функціонування владних інституцій у демократичній, соціальній, правовій державі, серед яких ключове значення мають такі:

- пріоритетність законодавчої регламентації функцій, повноважень та порядку діяльності органів місцевого самоврядування;

- незалежність здійснення їхніх функцій та повноважень від виконавчої, законодавчої і судової влади у межах, визначених Конституцією і законами України;

- здійснення внутрішнього та судового контролю за діяльністю органів місцевого самоврядування та їхніх посадових осіб, насамперед, з позиції забезпечення поваги до особи та справедливості, а також постійного підвищення ефективності управлінської іяльності на місцях;

- відповідальність органів місцевого самоврядування, їхніх посадових осіб за свої рішення, дії чи бездіяльність перед громадою та окремими громадянами, права яких були порушені;

- запровадження механізму контролю за функціонуванням місцевої влади з боку суспільства через громадянські інститути та засобами прямої демократії;

- принципи ефективності, відкритості та доброчесності в роботі органів та посадових осіб місцевого самоврядування.

Успіх інституціонального реформування місцевого самоврядування неможливий без активної участі самих місцевих посадовців у цьому процесі. Без залучення рядових чиновників до інституціональних перетворень, підвищення їхнього професіоналізму, відповідальності та порядності - існує реальна небезпека замість реформи отримати черговий популістський захід.

3 метою ефективного залучення усіх посадовців до процесу модернізації системи місцевої влади необхідно, насамперед, забезпечити конституційне право громадян щодо рівного доступу до служби в органах місцевого самоврядування. Існуюча непрозорість під час 64 
призначення на керівні посади у виконавчі органи влади на місцях вкрай негативно впливає на загальний морально-психологічний стан в органах місцевого самоврядування.

Відчутним стимулом щодо активного залучення рядових чиновників до процесу модернізації інститутів управління $є$ встановлення справедливої системи оплати праці. Заробітна плата молодого спеціаліста райдержадміністрації фактично дорівнює мінімальному прожитковому мінімуму і майже у 15 разів менше ніж в українського міністра. Натомість, у країнах ЄС цей показник не перевищує 7 (Мотренко, 2010).

Виклики сучасності актуалізують проблему розвитку місцвого самоврядування, розширення прав та повноважень територіальних громад через їх об'єднання, що в усьому світі розглядається як ознака демократичного вибору країни.

Відмітимо, що шляхи посилення дієвості та особливості організації місцевого самоврядування в умовах децентралізації влади, теоретико-методологічні підходи до забезпечення розвитку територіальних громад перебували в центрі уваги провідних фахівців у галузі права, державного управління, зокрема: В. Авер'янова, Г. Абасова, В. Бабаєва, О. Бабінової, В. Бакуменка, О. Батанова, Т. Безверхнюка, О. Бобровської, О. Богашко, Р. Войтовича, П. Ворони, Н. Грицяк, I. Дробота, В. Колтун, В. Корженка, В. Куйбіди, О. Лиски, П. Любченка, В. Мамонової, В. Мартиненка, Н. Нижник, М. Примуш, І. Софінської, Ю. Тодики, С. Телешуна, В. Шаповала, Ю. Шарова та ін.

Враховуючи вагомі наукові результати, отримані вченими та беручи до уваги сучасні трасформації в системі місцевого самоврядування, залишаються дискусійними і потребують додаткового теоретичного обгрунтування питання стратегії розвитку об'єднаної територіальної громади.

Крім того, важливим науковим завданням виступає комплексне дослідження теоретичних засад забезпечення розвитку об'єднаної територіальної громади.

Розробка теоретичних засад формування стратегії розвитку об'єднаної територіальної громади передбачає насамперед розкриття та аналіз базових категорій у такій послідовності: «територіальна громада», «розвиток», «об'єднана територіальна громада», «стратегія розвитку» «формування стратегії розвитку». Визначення територіальна громада не може бути здійснене без виявлення змісту категорії «громада». В тлумачному словнику української мови «громада» 
визначається як група людей, об'єднаних спільністю становища, інтересів (Тлумачний словник української мови, 2002).

Згідно $з$ визначенням, наведеним у «Енциклопедії державного управління», в загальному значенні «територіальна громада» $є$ спільнота людей, об'єднаних різноманітними стійкими формальними та неформальними зв' язками, які обумовлені спільним проживанням у межах села, селища, міста (Енциклопедія державного управління, 2011).

Згідно з Законом України «Про місцеве самоврядування в Україні» визначено наступне: територіальна громада - жителі, об'єднані постійним проживанням у межах села, селища, міста, що є самостійними адміністративно-територіальними одиницями, або добровільне об'єднання жителів кількох сіл, що мають єдиний адміністративний центр (Про місцеве самоврядування в Україні: Закон України,1997).

Наприклад, Орзіх М. вважає, що територіальна громада - це ... первинний суб'єкт місцевого самоврядування, який має власні інтереси, до складу якого входять громадяни України, іноземці, особи без громадянства, що постійно мешкають, або працюють на даній території, або володіють нерухомим майном, або сплачують місцеві податки та збори (Орзіх, 1995, с. 67).

Лисенко I. М. формулює категорію територіальна громада крізь призму спільності людей, об'єднана сталими взаєминами, проживаюча на певній території що здійснює самоврядування через місцеві референдуми, загальні збори, органи місцевої представницької влади (сільські, селищні, міські ради і так далі), органи самоорганізації населення та інші об'єднання громадян з метою реалізації своїх інтересів (Лисенко, 2009, с. 362).

Батанов О. В. сконструював нову теоретичну модель територіальної громади - як складну «кумулятивну форму суспільної організації, сукупність людей (місцевих жителів), асоційованих на публічних засадах у межах певної території та об'єднаних різноплановими ознаками системного характеру. За такого підходу, на його думку, відбувається реалізація приватних цілей у публічно-правовій формі (Батанов, 2008, с. 46).

На думку Кондрашова О.М., територіальна громада - це сукупність громадян України, котрі спільно проживають у міському чи сільському поселенні, мають колективні інтереси і визначений законом правовий статус (Мороз, 2008). 
Не одностайність думок серед науконауковців щодо змістовних та сутнісних характеристик дефініції «територіальна громада» у вітчизняній науці свідчить про іï постійну динаміку. Тому найбільш вдалим, на наш погляд, $є$ наступне визначення: територіальна громада - це складна соціальна система, що складається з різних підсистем та багатогранне суспільне явище, що перебуває у постійній динаміці.

Однією з головних цілей проведення об'єднання територіальних громад є економічна ефективність, а тому важливим чинником у цьому процесі має стати науково обгрунтоване формування стратегії розвитку територіальних громад.

Стратегія розвитку об'єднаної територіальної громади повинна характеризуватися кількома суттєвими рисами:

- зосереджується на тих напрямах розвитку громади, які становлять для неї найбільший шанс в майбутньому;

- характеризується точним, логічним записом, який випливає зі стратегічних напрямів розвитку в системі: стратегічних цілей, операційних цілей, завдань для реалізації;

- окреслює конкурентні переваги громади у відношенні до ближнього і дальнього оточення - творить стратегію динамічного розвитку;

- $є$ результатом праці представників всіх груп громади, починаючи з місцевої влади, організації і установ ради та завершуючи мешканцями. Це дозволяє отримати пропозиції цілей та завдань від усіх зацікавлених сторін, а також сприйняття представниками місцевої спільноти рішень та завдань, які приймаються в рамках стратегії;

- пов' язана з іншими документами страте гічного характеру.

На цей час розроблено Концепцію реформування місцевого самоврядування та План ії реалізації, які фактично є лише рамковими документами впровадження реформ, варто зазначити офіційні документи, котрі визначають основні етапи, умови та власне процес добровільного об'єднання територіальних громад, а також функції та обов'язки, яких набудуть об'єднані територіальні громади, і фінанси, які будуть надані для їх реалізації після завершення процедури об'єднання. Це, зокрема: Закони України «Про співробітництво територіальних громад» (від 17.06.2014 р. № 1508-18), «Про добровільне об'єднання територіальних громад» (від 05.02.2015 р. № 157-19), «Про засади державної регіональної політики» (від 05.02.2015 р. № 156-VIII), Бюджетний кодекс України, зі змінами, прийнятими Верховною Радою України від 10.02.2015 р. № 156-VIII, Методика формування 
спроможних територіальних громад, затверджена постановою Кабінету Мінстрів України від 08.04.2015 р. № 214.

У разі об'єднання, громади наділяються повноваженнями та ресурсами, як у міст обласного значення. Натомість територіальні громади, які не візьмуть участь у об'єднанні, залишаються осторонь цього процесу та позбавляються права на виконання делегованих державою повноважень органів місцевого самоврядування в селах, селищах, містах районного значення, що не об'єдналися.

Українське місцеве самоврядування одночасно перебуває під впливом двох соціально-політичних систем - європейської демократії та пострадянської вертикальної ієрархії владних відносин. На практиці це означає, що політична трансформація місцевого самоврядування охоплює тільки зовнішне ії наповнення (побудова політичних інститутів за певним зразком, впровадження законних та підзаконних актів щодо реалізації положень Європейської Хартії тощо). Стратегічними напрямами розвитку територіальних громад визначено: 1) створення сучасної соціальної інфраструктури громади; 2) ефективне використання обмежених природних ресурсів місцевого значення для задоволення потреб громади; якісне надання послуг; 3) підтримку бізнесового середовища та створення максимальної кількості робочих місць шляхом формування сприятливого інвестиційного клімату на території громади; 4) випереджальну кадрову політику для соціальної сфери; 5) співпрацю з фондами й радами іншого рівня, що дає можливість додаткового співфінансування програм розвитку територіальних громад чи вирішення окремих актуальних питань та посилює місцеві бюджети; 6) співпрацю з громадськістю, у тому числі через консультації з мешканцями громади з актуальних питань. Узагальнивши початковий етап децентралізації влади та місцевого самоврядування поділяємо висновки експертних наукових кіл, які вказують на низку стратегічних і тактичних вад чинної моделі реформи місцевого самоврядування. У стратегічному плані залишається невизначеним та нечітким інструментарій досягнення таких пріоритетів: деолігархізації регіонального розвитку та забезпечення територіальної цілісності в умовах зовнішніх загроз та наростання відцентрових тенденцій на центральному та регіональному рівнях. У тактичному плані недостатньо зусиль $з$ підтримкти та заохочення самоврядних засад реформи. 3-поміж цих проблем: а) обмеженість повноважень та нечітке розмежування функцій між центром та регіонами; б) високий рівень бюджетно-фінансової 
залежності місцевих бюджетів від центру; в) невирішеність питань пов'язаних з землевідведенням, реєстру прав на землю на місцевому рівні; г) застарілий адміністративно-територіальний устрій, що не відповідає вимогам часу і сучасним викликам. Практична реалізація реформи показала, що бюджетна децентралізація призводить до неоднозначних результатів, зокрема посилює залежність місцевих бюджетів від трансферів з центрального бюджету, зниження рівня соціальних видатків тощо. Проблематичним є задеклароване проведення добровільного об'єднання громад, розширення повноважень місцевих громад щодо користування земельними ресурсами, зміна адміністративно-територіального устрою України.

3-поміж пропозицій подальшого вдосконалення децентралізації влади та реформи місцевого самоврядування слід наголосити на наступних:

1) впроваджувана модель децентралізації не передбачає запобіжників щодо посилення стихійної фрагментації України, а тому державну політику децентралізації необхідно доповнити розробкою і прийняттям Концепції реінтеграції України, що передбачає зокрема: а) запровадження системи управління просторовим розвитком та управління на макрорегіональному рівні; б) створення та запровадження моделі міжрегіональної співпраці та кооперації областей України; в) подолання регіональної самозамкненості та формування єдиного економічного, інформаційного та соціокультурного простору та ін.;

2) найбільшим ризиком реформи децентралізації $\epsilon$ «олігархічна децентралізація», що означає проведення реформи місцевого самоврядування в інтересах регіональної бюрократії, «баронів» і олігархії. Запобіжник цьому, на думку аналітиків, - проведення реформи місцевого самоврядування у два етапи. На першому етапі повноваження повинні отримати територіальні громади міст та селищ. I лише на другому має вирішуватись питання щодо обсягу повноважень та моделі функціонування інститутів регіонального самоврядування в Україні;

3) подальша реалізація реформи місцевого самоврядування та децентралізації влади безумовно передбачає внесення змін до Конституції України шляхом двох сценаріїв - оптимізації» та «модернізації;

4) на завершальному етапі реформи місцевого самоврядування необхідно буде запровадити більш оптимальну модель територіальної 
організації влади та провести реформу адміністративнотериторіального устрою. Фахівці пропонують з метою формування конкурентоспроможних та здатних до саморозвитку територіальних та місцевих громад здійснити їх об'єднання за територіальним принципом у функціональні регіони (землі), врахувавши економічні, інфраструктурні, природно-ресурсні, культурні, етнічні, мовні та релігійні уподобання населення;

5) розвиток муніципальної економіки України має стати центральним елементом і метою здійснення економічних реформ та політики децентралізації.

\section{Висновки}

Як відповідь на проблеми інституційного розвитку в Україні видокремлено пріоритетні завдання влади виходячи з взятих державою зобов' язань перед Європейським Союзом щодо реформування місцевого самоврядування:

1) Приведення чинного національного законодавства у відповідність з положеннями Свропейської хартії місцевого самоврядування. Забезпечення дотримання принципів Свропейської хартії в нормативно-правових актах, що стосуються місцевого самоврядування.

2) Оптимізація територіальної основи базового рівня місцевого самоврядування для забезпечення його матеріально-фінансової, інфраструктурної, кадрової спроможності здійснювати повноваження щодо надання належного рівня якості публічних послуг громадянам, а також для інтенсифікації місцевого економічного розвитку.

3) Передача повноважень з надання основних публічних послуг на рівень органів місцевого самоврядування укрупнених територіальних громад, а повноважень 3 контролю за відповідністю якості надання зазначених послуг державним стандартам - місцевим органам виконавчої влади.

4) Створення власних виконавчих органів районних та обласних рад 3 повноваженнями щодо виконання завдань соціальноекономічних розвитку та життєзабезпечення відповідних територій.

5) Подальше вдосконалення виборчої системи в напрямі дотримання демократичних принципів реалізації волевиявлення громадян, забезпечення ефективних механізмів обрання на посади сільських, селищних, міських голів висококваліфікованих фахівців та формування якісного депутатського корпусу місцевих рад. 
6) Впровадження механізмів та європейських практик доброго врядування на місцевому рівні, тісніше залучення громадян до процесу підготовки та прийняття рішень на місцевому рівні.

7) Забезпечення узгодження інтересів державної влади та місцевого самоврядування, в тому числі в питаннях раціонального розподілу повноважень та фінансових ресурсів для їх реалізації відповідно до європейських принципів та за механізмами, передбаченими законодавством про місцеве самоврядування.

Стратегія розвитку - це документ, який містить принципи (припущення), прийняті під час реалізації процесу планування. Планування становить особливий вид прийняття рішень, що займається тим конкретним майбутнім, якого головні місцеві середовища прагнуть для своєї територіальної громади, і якого можливо досягнути з огляду на вплив різноманітних факторів.

Місцеве самоврядування як інститут громадянського суспільства повинне мати єдине тлумачення у вітчизняному законодавстві і базуватись на ратифікованій Свропейській Хартії місцевого самоврядування.

Запропоновано удосконалене визначення: місцеве самоврядування - реалізоване територіальною громадою право на самоорганізацію місцевого розвитку за умов повного використання місцевих ресурсів за гарантованої державою правової, фінансової та організаційної автономії та за вільного волевиявлення ії мешканців.

Метою Концепції реформування місцевого самоврядування та територіальної організації влади в Україні $є$ визначення напрямів, механізмів та строків формування ефективного місцевого самоврядування та територіальної організації влади, спроможної максимально забезпечити передовсім надання якісних та доступних адміністративних, соціальних та інших послуг, становлення інститутів демократії участі, задоволення інтересів громадян в усіх сферах життєдіяльності на відповідній території, узгодження інтересів держави та територіальних громад.

Ефективна реалізація основних засадах реформування місцевого самоврядування та територіальної організації влади в Україні, що логічно випливають 3 концепції, вимагає термінового позбуття неефективного спадку попередніх років, зокрема: 1) високої концентрації державної влади з ознаками ії узурпації; 2) централізації бюджетних фінансів, їх перерозподіл «вниз» в ручному режимі; 3) великої залежності територій від дій центральної вдади та поділу їх на «своїх» 
та чужих»; 4) розбалансованості системи місцевого самоврядування; 5) безмежної корупції.

Стратегічними напрямами розвитку територіальних громад визначено: 1) створення сучасної соціальної інфраструктури громади; 2) ефективне використання обмежених природних ресурсів місцевого значення для задоволення потреб громади; якісне надання послуг; 3) підтримку бізнесового середовища та створення максимальної кількості робочих місць шляхом формування сприятливого інвестиційного клімату на території громади; 4) випереджальну кадрову політику для соціальної сфери; 5) співпрацю з фондами й радами іншого рівня, що дає можливість додаткового співфінансування програм розвитку територіальних громад чи вирішення окремих актуальних питань та посилює місцеві бюджети; 6) співпрацю з громадськістю, у тому числі через консультації з мешканцями громади з актуальних питань.

Аналіз соціологічних даних про перші результати реформи децентралізації та місцевого самоврядування дозволяє резюмувати. Більшість населення обізнана із реформою. Більше 60 \% українців вказують на покращення ситуації, або очікують цього. Люди у громадах акцентують увагу на позитивних змінах з освітленням вулиць, облаштуванням соціальної сфери, ремонтом бюджетних приміщень, простежується хоч і незначна динаміка зростання очікувань на покращення ситуації. «Обережний» оптимізм прослідковуються у половини громадян, що реформа децентралізації і місцевого самоврядування сприятиме розвитку громад України.

\section{Лimepamypa:}

Батанов, О. (2008). Територіальна громада - первинний суб'єкт муніципальної влади в Україні: поняття та ознаки. Вісник центтральної виборчої комісії, 2(12), 46-52.

Батанов, О. В. (2006). Функції муніципальної влади: поняття та класифікація. Бюлетень Міністерства юстииї Украӥни, 11 (61), 17-29.

Бюджетний кодекс України: Закон України від 08.07.2010 № 2456-VI (Верховна Рада України). Офіиійний сайт Верховної Ради України. URL: http:/ / zakon.nau.ua/doc/?uid=1011.44.0.

Енциклопедія державного управління: у 8 т. (2011); Нац. акад. держ. упр. При Президентові України; наук.-ред. колегія: Ю. В. Ковбасюк (голова) та ін. Т. 5: Територіальне управління / наук.-ред. колегія: 
О. Ю. Амосов (співголова), О. С. Ігнатенко (співголова) та ін.; за ред. О. Ю. Амосова, О. С. Ігнатенка, А. О. Кузнецова. Х.: Вид-во ХарРІ НАДУ «Магістр».

Коваленко, А. А. (1997). Конституційно-правове регулювання місиевого самоврядування В Украӥні: питання теорії та практики. К.: Довіра.

Копєйчиков, В. В. (1995). Державна влада і питання формування громадянського суспільства в Україні. Правова держава, Вип. 6, 29-38.

Кравченко, И. И. Новая философская энциклопедия: в 4 т.; под ред. В. С. Стёпина. М.: Мысль.

Лисенко, I. М. (2009). Територіальна громада в системі громадянського суспільства. Науковий вісник «Гілея», Вип. 28, 362-372.

Методика формування спроможних територіальних громад: постанова Кабінету Міністрів України від 08.04.2015p. № 214 (Кабінет Міністрів України). Офіційнии сайт Верховної Ради України. URL: http://zakon4.rada.gov.ua/laws/show/214-2015-\%D0\%BF.

Мороз, О. Ю. (2008). Територіальна громада : сутність становлення та сучасні українські реалії. Демократ. врядування : електрон. наук. фах. Видання, Вип. 2. URL: www.nbuv.gov.ua.

Мотренко, Т. В. (2010). Порядок денний адміністративної реформи. Урядовий кур'єр, 27 берез.

Орзіх, М. (1995). Концепція правового статусу самоврядних територій і органів місцевого самоврядування. Місиеве та регіональне самоврядування Украӥни, Вип. 12(10-11), 67-75.

Политическая наука: словарь-справочник / сост. проф. И. И. Санжаревский (2010). М.: Знамя.

Про добровільне об'єднання територіальних громад: Закон України від 05.02.2015 № 157-VIII (Верховна Рада України). Офіиіииний сайт Верховної Ради України. URL: http:/ / zakon4.rada.gov.ua/laws/show/157-viii.

Про засади державної регіональної політики: Закон України від 05.02.2015 № 156-VIII (Верховна Рада України). Офіиійний сайm Верховної Ради України. URL: http:/ / zakon4.rada.gov.ua/laws/show/156-19.

Про місиеве самоврядування в Україні: Закон України від 21.05.1997 № 280/97-ВР (Верховна Рада України). Офіційний сайт Верховної Ради України. URL: http://zakon0.rada.gov.ua/laws/show/280/97\%D0\%B2\%D1\%80. 
Про співробітництво територіальних громад: Закон України від 17.06.2014 № 1508-VII (Верховна Рада України). Офіиійний сайm Верховної Ради України. URL: http:/ / zakon4.rada.gov.ua/laws/show/1508-18.

Тлумачний словник української мови / укладачі Т. В. Ковальова, Л. П. Коврига (2002). Харків: Синтекс.

\section{References:}

Batanov, O. (2008). Tery`torial`na gromada - pervy`nny`j sub’yekt municy`pal`noyi vlady` v Ukrayini: ponyattya ta oznaky` [Territorial community as the primary subject of municipal government in Ukraine: concepts and features]. Visny'k central 'noyi vy 'borchoyi komisiyi [Bulletin of the Central Election Commission], 2(12), 46-52. [in Ukrainian].

Batanov, O. V. (2006). Funkciyi municy`pal`noyi vlady`: ponyattya ta klasy fikaciya [Functions of the municipal government: concept and classification]. Byuleten 'Ministerstva yusty 'ciyi Ukrayiny' [Bulletin of the Ministry of Justice of Ukraine], 11 (61), 17-29. [in Ukrainian].

Byudzhetny`j kodeks Ukrayiny`: Zakon Ukrayiny`vid 08.07.2010 \# 2456-VI [Budget Code of Ukraine: Law of Ukraine dated 08.07.2010 No. 2456VI] (Verxovna Rada Ukrayiny'). Oficijny ’ sajt Verxovnoyi Rady Ukrayiny' [Official site of the Verkhovna Rada of Ukraine]. URL: http:/ / zakon.nau. ua/doc/?uid=1011.44.0. [in Ukrainian].

Ency klopediya derzhavnogo upravlinnya: u 8 t. (2011) [Encyclopedia of Public Administration: 8 volumes]; Nacz. akad. derzh. upr. Pry` Prezy`dentovi Ukrayiny`; nauk.-red. kolegiya: Yu. V. Kovbasyuk (golova) ta in. T. 5: Tery 'torial ne upravlinnya / nauk.-red. kolegiya: O. Yu. Amosov (spivgolova), O. S. Ignatenko (spivgolova) ta in.; za red. O. Yu. Amosova, O. S. Ignatenka, A. O. Kuzneczova. Kharkiv: Vy`d-vo XarRI NADU "Magistr". [in Ukrainian].

Kopyejchy`kov, V. V. (1995). Derzhavna vlada i py`tannya formuvannya gromadyans`kogo suspil`stva v Ukrayini [State power and issues of civil society formation in Ukraine]. Pravova derzhava [Constitutional state], Vy`p. 6, 29-38. [in Ukrainian].

Kovalenko, A. A. (1997). Konsty tucijno-pravove regulyuvannya miscevogo samovryaduvannya v Ukrayini: py 'tannya teoriyi ta prakty 'ky' [Constitutional and legal regulation of local self-government in Ukraine: issues of theory and practice]. Kyiv: Dovira. [in Ukrainian]. 
Kravchenko, I. I. (2001). Novaya filosofskaya entsiklopediya: v 4 t. [New philosophical encyclopedia: in 4 volumes]; pod red. V.S. Stepina. Moscow: Mysl. [in Russian].

Ly`senko, I. M. (2009). Tery`torial`na gromada v sy`stemi gromadyans`kogo suspil'stva [Territorial community in the system of civil society]. Naukovy`j visny`k «Gileya» [Gilea Scientific Bulletin], Vy`p. 28, 362-372. [in Ukrainian].

Metody 'ka formuvannya spromozhny'x tery torial 'ny'x gromad: postanova Kabinetu Ministriv Ukrayiny`vid 08.04.2015r. \# 214 [Methods of formation of capable territorial communities: Resolution of the Cabinet of Ministers of Ukraine dated April 8, 2015 № 214] (Kabinet Ministriv Ukrayiny`). Oficijny 'j sajt Verxovnoyi Rady' Ukrayiny' [Official site of the Verkhovna Rada of Ukraine]. URL: http:/ / zakon4.rada.gov.ua/laws/show/214-2015$\% \mathrm{D} 0 \% \mathrm{BF}$. [in Ukrainian].

Moroz, O. Yu. (2008). Tery`torial`na gromada : sutnist` stanovlennya ta suchasni ukrayins`ki realiyi [Territorial community: the essence of becoming and modern Ukrainian realities]. Demokrat. vryaduvannya: elektron. nauk. fax. Vy'dannya [Democrat. governance: electron. Sciences. profession. Editions], Vy`p. 2. URL: www.nbuv.gov.ua. [in Ukrainian].

Motrenko, T. V. (2010). Poryadok denny`j administraty`vnoyi reformy [Administrative reform agenda]. Uryadovy ’ k kur'yer [Government Courier], 27 berez. [in Ukrainian].

Orzix, M. (1995). Koncepciya pravovogo statusu samovryadny`x tery`torij i organiv miscevogo samovryaduvannya [The concept of legal status of self-governing territories and local self-government bodies]. Misceve ta regional ne samovryaduvannya Ukrayiny' [Local and Regional SelfGovernment of Ukraine], Vy`p. 12(10-11), 67-75. [in Ukrainian].

Politicheskaya nauka: slovar-spravochnik / sost. prof. I. I. Sanzharevskiy [Political science: dictionary / comp. prof. I.I. Sanzharevsky] (2010). Moscow: Znamya. [in Russian].

Pro dobrovil ne ob'yednannya tery torial 'ny'x gromad: Zakon Ukrayiny` vid 05.02.2015 \# 157-VIII [On voluntary association of territorial communities: Law of Ukraine of 05.02.2015 № 157-VIII] (Verxovna Rada Ukrayiny'). Oficijny ’j sajt Verxovnoyi Rady Ukrayiny' [Official site of the Verkhovna Rada of Ukraine]. URL: http://zakon4.rada.gov.ua/ laws/show/157-viii. [in Ukrainian]. 
Pro misceve samovryaduvannya v Ukrayini: Zakon Ukrayiny` vid 21.05.1997 \# 280/97-VR [On Local Self-Government in Ukraine: Law of Ukraine of May 21, 1997 \# 280/97-BP] (Verxovna Rada Ukrayiny'). Oficijny j sajt Verxovnoyi Rady 'Ukrayiny ' [Official site of the Verkhovna Rada of Ukraine]. URL: http:/ / zakon0.rada.gov.ua/laws/show/280/97-\%D0\%B2\%D1\%80. [in Ukrainian].

Pro spivrobitny 'cztvo tery ‘torial 'ny ‘ $x$ gromad: Zakon Ukrayiny` vid 17.06.2014 \# 1508-VII [On Cooperation of Territorial Communities: Law of Ukraine of 17.06.2014 No. 1508-VII] (Verxovna Rada Ukrayiny'). Oficijny j sajt Verxovnoyi Rady 'Ukrayiny ' OOfficial site of the Verkhovna Rada of Ukraine]. URL: http:/ / zakon4.rada.gov.ua/laws/show/1508-18. [in Ukrainian].

Pro zasady derzhavnoyi regional noyi polity 'ky': Zakon Ukrayiny` vid 05.02.2015 \# 156-VIII [On the Principles of State Regional Policy: Law of Ukraine of 05.02.2015 No. 156-VIII] (Verxovna Rada Ukrayiny'). Oficijny `j sajt Verxovnoyi Rady` Ukrayiny [Official site of the Verkhovna Rada of Ukraine]. URL: http:/ / zakon4.rada.gov.ua/laws/show/156-19. [in Ukrainian].

Tlumachny`j slovny`k ukrayins `koyi movy / ukladachi T. V. Koval’ova, L. P. Kovry`ga (2002) [Ukrainian Language Interpreters/ Compilers TV Kovaleva, LP Kovryga]. Kharkiv: Sy`nteks. [in Ukrainian].

\section{Анотація}

Мішин С. I. Теоретико-методологічні засади реформування системи місиевого самоврядування. - Стаття.

У статті розглянуто місцеве самоврядування, як комплексна галузь українського права, що є сукупністю правових норм, які закріплюють і регулюють суспільні відносини, щзо виникають у процесі організації місиевого самоврядування і вирішення територіальною громадою безпосередньо через органи місиевого самоврядування питань місиевого значення, а також у процеесі реалізації окремих державних повноважень, якими можуть наділятися органи місиевого самоврядування.

Встановлено, що необхідною умовою динамічного розвитку України є інституиійне реформування органів влади на місиях. Це дозволить подолати їхне дублювання функиіий $і$ нестаток прозорості, а також призведе їх у відповідність до ринкових умов. Особливої уваги при иъому, як у теоретичному, так і у практичному сенсі заслуговуе вивчення особливостей впливу посттоталітарної спадщини на розвиток владних інституиій, механізми досягнення балансу між легалізацією та легітимацією влади за допомогою ефективного розв'язання існуючих протиріч. 
У науково-теоретичному аспекті місиеве самоврядування характеризується як особливии інститут, який у своїи основі має не державу чи державну владу, які засновані на матеріальній базі державної власності, а громадську спільноту, общину, матеріальною базою якої є зовсім інша форма власності - муніципальна.

Місиеве самоврядування на практиці втілює інтереси територіальних громад. При изьому роль місцевого самоврядування для процесів просторової організації публічної влади пояснюється тим, щцо влада територіальних громад, будучи самостіиним видом публічної влади, за своїм суб'єктнооб'єктним складом, своєю природою та сутністю, діапазоном здійснюваних нею функиій є найбільщ соціально орієнтованою фрормою здійснення публічної влади, а також виступае потужним каталізатором формування громадянського суспільства, оскільки свідома участь жителів у процесі утворення гідних умов життя на певній території сприяе формуванню у них відповідальності за вирішення місцевих проблем і тим самим підвищууе їх загальну соціальну та громадянську активність.

Ключові слова: місиеве самоврядування, територіальна община, об'єднана територіальна громада, перспективний план, децентралізація, реформування місиевого самоврядування. 